\title{
How useful are skills acquired at adult non-formal education and training centres for finding employment in South Africa?
}

\author{
Celestin Mayombe ${ }^{1} *$ and Antoinette Lombard ${ }^{1}$
}

*Correspondence author: Celestin Mayombe

celestin-may@hotmail.com

Antoinette Lombard

antoinette.lombard@up.ac.za

${ }^{1}$ Department of Social Work and Criminology, University of Pretoria, Private bag X20, Hatfield 0028, South Africa

\begin{abstract}
Non-formal adult education and training (NFET) in South Africa is instrumental in breaking the high level of poverty and decreasing the social inequality the country continues to face as a post-apartheid democracy. Public and private NFET centres in South Africa aim to meet the training needs of adults who have been deprived of formal education with courses which foster access to opportunities for skills acquisition and employment and bring about social and economic inclusion. However, many adults who were facing long-term unemployment due to a lack of marketable skills remain unemployed after completing NFET programmes. This paper reports on a study which investigated what constitutes favourable conditions ("internal enabling environments") for skills acquisition inside NFET centres leading to employment and how they can be improved to contribute to coordinated efforts of increasing NFET graduates' paid and/or self-employment capacities. The authors found that centres focusing on activities suitable for self-employment during training were more likely to create internal enabling environments for skills acquisition and income generation than centres offering courses designed for entering paid employment. The authors conclude that there appears to be a significant correlation between NFET centres' training programme objectives, financial resources, trainee selection criteria, the process of training needs assessment, and skills acquisition for successful employment outcomes of NFET graduates. Without these internal enabling factors, adult trainees are likely to continue finding it difficult to integrate into the labour market or participate in economic activities and hence break the cycle of poverty and social exclusion.
\end{abstract}

\section{Keywords}

Non-formal education and training Skills acquisition Training needs assessment Internal enabling environments Adult education Human capital theory South Africa

\section{Résumé}

Les compétences acquises dans les centres d'éducation et de formation non formelles des adultes aident-elles à trouver un emploi en Afrique du Sud ? - L'éducation et la formation non formelles des adultes jouent en Afrique du Sud un rôle important pour baisser sensiblement le taux élevé de pauvreté et réduire les inégalités sociales, auxquels cette démocratie post-apartheid est encore confrontée. Les centres publics et privés d'éducation et 
de formation non formelles des adultes visent dans le pays à répondre aux besoins éducatifs des adultes qui n'ont pas été scolarisés, par des mesures qui leur ouvrent l'accès à l'acquisition de compétences et à l'emploi et favorisent leur intégration sociale et économique. Néanmoins, de nombreux adultes qui étaient chômeurs de longue durée par manque de compétences monnayables demeurent sans emploi après avoir accompli un programme dans ces centres. Cet article présente une étude sur la nature des conditions favorables (les « environnements internes propices ») pour acquérir dans ces centres des compétences qui débouchent sur un emploi, et sur les moyens de les renforcer pour contribuer aux efforts conjugués d'augmenter la rémunération des stagiaires sortants et/ou leurs capacités d'auto-emploi. Les auteurs constatent que les centres qui privilégient des activités adaptées à un travail indépendant pendant la formation sont plus susceptibles de créer des environnements internes propices à l'acquisition de compétences et la création de revenus, que les centres qui proposent des cours destinés à obtenir un emploi salarié. Les auteurs en concluent qu'il semble exister un lien significatif entre objectifs des programmes de formation de ces centres, ressources financières, critères de sélection des participants, système d'évaluation des besoins en formation, et acquisition de compétences en vue d'une embauche concluante pour les stagiaires sortants. En l'absence de ces facteurs internes propices, il est probable que les apprenants adultes continuent à rencontrer des difficultés à intégrer le marché du travail ou à participer à des activités économiques, et ainsi à rompre le cercle vicieux de la pauvreté et de l'exclusion sociale.

\section{Introduction}

Adult non-formal education and training (NFET) has become relevant in the pursuit of the global "Education for All" campaign and the Millennium Development Goals (MDGs) (Jjuuko and Kwiri 2010). In the 1960s and 1970s, NFET was perceived to offer a secondchance education to those who had been pushed out of the formal educational system and foster their employment opportunities (Kedrayate 2012; Georgiadou et al. 2009).

In South Africa, NFET was adopted in 1990 with the aim to respond to the learning needs of adults who did not have access to formal education; to increase their employment opportunities; to reduce the high rates of poverty and to enhance social inclusion (Aitchison 2007). However, poverty due to unemployment among non-educated and unskilled adults has increased more than was expected in the post-apartheid period (Anderson 2012; May 2010). To redress the historical lack of education and training and promote lifelong learning, the South African government legislated NFET through the Adult Education and Training (AET) Act 25 of 2010 (RSA 2010). NFET targets those adults who have no access to formal vocational training systems, such as, for example, Further Education and Training (FET) colleges (DHET 2012). To this end, the Act stipulates that NFET centres, in collaboration with government departments, private institutions and various stakeholders, should create an "enabling environment" for the utilisation of the skills acquired at NFET centres in the labour market (RSA 2010).

The term "enabling environment" refers to factors which create conducive conditions either for skills acquisition inside the NFET centre ("internal enabling environment") or for skills utilisation in employment outside the NFET centre ("external enabling environment"), or helping NFET graduates start their own small enterprises in a sustained and effective manner (King and Palmer 2006; World Bank 2004). In this paper, "training delivery" of internal enabling environments for skills acquisition refers to internal factors within the NFET centre which create conducive conditions for skills acquisition (Palmer 2007). 
Despite existing research on the dynamics of the relationship between NFET programmes and employment strategies, there is still insufficient knowledge available on the internal factors which enhance skills acquisition at NFET centres and their external application in the labour market. Previous research has addressed several aspects of NFET, including the examination of the relevance of NFET for income generation (Islam et al. 2012; Blaak et al. 2012); acquisition of practical skills (Georgiadou et al. 2009; Islam et al. 2012); socioeconomic empowerment of adults who are poor (Morton and Montgomery 2011; Akpama et al. 2011); the ineffectiveness of NFET; and skills mismatch in terms of supply and demand on the labour market (Morton and Montgomery 2011; Anderson 2012). Research has shown that NFET centres and their adult trainees continue to experience challenges due to the insufficiency of enabling environments (DHET 2012; Aitchison 2007; Blaak et al. 2012).

Despite widespread concerns expressed in the literature about the exclusion of NFET graduates from the labour market, remarkably little has been done in terms of analysing the internal enabling environments of NFET centres, thereby attempting to understand the nature of the problem, and what should be done to solve it. This paper reports on a study investigating what constitutes internal enabling environments for employment and how they can be improved to contribute to coordinated efforts towards increasing NFET graduates' paid and/or self-employment capacities. The data were collected between January 2013 and April 2014. The study was informed by the concern that adults who face long-term unemployment due to a lack of marketable skills remain unemployed after completing NFET programmes. Our paper investigates the extent to which the internal enabling environments of adult NFET centres in KwaZulu-Natal, South Africa, are conducive to skills acquisition and employment.

The KwaZulu-Natal Department of Education offers two important types of NFET programmes for adults who have no or little formal education. The first type is the formal educational system linked to the National Qualification Framework (NQF) structure, and in part to Adult Education and Training (AET) which facilitates the adult learner's progression through AET levels 1-4. The first type of programme covers AET levels 1-3, which is equal to high school, also known as "second-chance" schooling (ibid.). It provides "an educational level equivalent to the Adult Secondary Education Curriculum for Adults" (ibid., p. 36). The second type is AET level 4, which is linked to livelihood skills. Level 4 culminates in a General Education and Training Certificate (GETC) at the end of the programmes (KZN-DoE 2012). It is this second type of NFET programme which is relevant for the focus of this study. It encompasses training unemployed adults from rural and urban backgrounds in technical and entrepreneurial skills to enable them to take up paid or self-employment in the fields of agriculture, industry, services or small business activities.

Our paper begins with a look at the demographic distribution of poverty in South Africa, followed by a consideration of poverty reduction strategies involving NFET. Next, the focus is on internal enabling environments of adult NFET centres for skills acquisition and employment. After a description of the research context and methodology of the study, we present and discuss our findings. The article wraps up with a number of conclusions and recommendations.

\section{Demographic distribution of poverty in South Africa}

The long-term negative legacy of apartheid is still evident in the social and economic character of poverty in South Africa. Several studies (KZN-DoH 2010; Pauw 2009; May 
2010) indicate that KwaZulu-Natal, Eastern Cape and Limpopo are the poorest three among the nine provinces in the country. Between $63 \%$ and $82 \%$ of households in these three provinces are living on less than USD 65 per month (May 2010). A demographic analysis of poverty can be made by considering the following strata: race, gender, unemployment, and the relationship between unemployment and level of education.

Race. Poverty in South Africa has strong racial dimensions. At any poverty line, Africans are much poorer than Coloureds, who are much poorer than Indians/Asians, followed by Whites who are the least poor (Leibbrandt et al. 2010). Findings from a study by Paula Armstrong et al. (2008) indicate the extent of poverty among races as being $54.8 \%$ for Black Africans, $34.2 \%$ for Coloureds, $7.1 \%$ for Indians and $0.4 \%$ for Whites.

Gender. There is also a relationship between gender and poverty in South Africa. Statistics South Africa (2011) reported that about $47.4 \%$ of the poor were females compared to $38.6 \%$ who were males. In 2008, the poverty rate among female-headed households was $60 \%$, while it was $31 \%$ among male-headed households (Woolard et al. 2009). Furthermore, data from household surveys in South Africa demonstrate that households headed by females have a greater predisposition towards being poor (Roberts 2008).

Unemployment. The interrelatedness between poverty and unemployment in South Africa is revealed in the Labour Force Survey (first quarter) (Statistics South Africa 2014), revealing that the national unemployment rate is $25.2 \%$. Among the unemployed, Black Africans represent $29.1 \%$, Coloureds $23.9 \%$, Indians $9.3 \%$, and Whites $6.1 \%$. Moreover, labour force participation is lower in poor households.

Relationship between unemployment and level of education. Unemployment and poverty are related to levels of education. In South Africa and elsewhere, it has been argued that adults with low attainment levels of education and training are much more likely to be poor than well-educated ones. Simon McGrath and Salim Akoojee (2007) point out that approximately $58 \%$ of those in paid employment have at least a matriculation level of education (having completed 12 years of schooling), compared to only $38 \%$ in the total working-age population. Highlighting the link between educational achievement and household poverty, a household survey conducted by Benjamin Roberts (2008) reveals that levels of adult illiteracy are particularly high in chronically poor households. The survey by Armstrong et al. (2008) already mentioned above revealed that poverty (as measured by the poverty line) ${ }^{1}$ affected $66.3 \%$ of those who had no schooling and $59.9 \%$ of those who had not completed primary schooling.

Adult education and training play a key role in addressing the social and economic inequalities in South Africa and reducing poverty particularly in rural areas and especially with regard to racial groups and gender, as will be discussed in the next section.

\section{Non-formal education and training and poverty reduction}

It is widely agreed that the poor in developing countries usually have low education levels. Some poor people may still not even have access to primary education or may not have completed their primary education (Preece 2005). There are strong debates in support of adult NFET programmes focusing on the teaching of livelihood skills which enable the poor to develop the required capabilities to free themselves from poverty and deprivation (Jjuuko and Kwiri 2010). Therefore, as Robert Palmer et al. (2007) argue, the poverty reduction approach 
which intends to lift people out of their hardship includes education and training as one of the key sectoral strategies. Similarly, Julia Preece points out that "Educated and skilled parents are generally seen to produce healthier children with potential consequences for preventing poverty in the next generation (Preece 2010, p. 482)."

Social assistance and the Expanded Public Works Programme (EPWP) ${ }^{2}$ form an important part of the South African government's strategy to fight poverty, inequality and unemployment (RSA 2012). However, for purposes of skills acquisition, the poverty reduction process required a reconceptualisation of adult education in South Africa which emerged from different laws and policies on adult education and training. NFET was conceptualised as a programme situated between formal and informal education and is sometimes referred to as para-formal education (Aitchison 2007). While NFET is seen as complementary to the formal system, by definition it does not include formal certification. Some attention is therefore now being given to non-formal qualifications enabling people to move across (back) into the formal system at the appropriate levels (ibid.).

\section{Internal enabling environments of adult NFET centres for skills acquisition and employment}

Internal enabling environments for skills acquisition and employment entail three distinct but integrated "delivery environments", namely material resources, human resources and enabling NFET centre governance (Palmer 2007). Material resources include availability of textbooks and other learning materials, tools, classroom infrastructure (including workshops for skills training), centre facilities and curriculum contents (Palmer 2007; UNESCO 2005). The availability of human resources is especially important for effective NFET training delivery and involves centre managers, administrators, other support staff, supervisors, inspectors, and, crucially, qualified instructors or trainers with experience in adult education and training for income-generating activities (Dunkley 2008). Finally, enabling centre governance concerns the ways in which the NFET centre is organised and managed and plays a vital role in designing training curricula and contents, facilitating good linkages with public institutions and agencies, linkages with social networks, associations and employers, and providing support after the completion of training programmes (UNESCO 2005). These three delivery environments also need to be interlinked. If they are not, the environments become disabling for both paid and self-employment.

A study conducted by Marit Blaak et al. (2012) in Uganda revealed that although the training centres in that country did focus on both paid employment and self-employment, the emphasis was on paid employment, despite the fact that there were not enough jobs for lowskilled trainees. As a result, the programmes failed to have a positive impact on employment outcomes. Similarly, in the context of India, Palmer (2008) reports that training centres which focus on a single objective, be it paid or self-employment, have specific training delivery components and activities designed to ensure that the objective is achieved. The training is tailored in accordance with the local market demand with the specific objective being either paid employment or self-employment. Palmer (ibid.) concludes that a training programme without a clear objective for the beneficiaries limits the employment outcome.

An earlier study conducted by Kenneth King and Robert Palmer (2007) in Ghana revealed that a lack of training centres' financial resources was one of the challenges hindering positive employment outcomes of the Skills Training and Employment Placement (STEP) programme. The centres' training delivery was weak due to insufficient tools and equipment. 
The consequence of this disabling environment was that the skills training programme was leading to the creation of "half-baked" skills acquisition (ibid., pp. 50-51).

A number of more recent studies confirm the link between trainee selection procedures and the effectiveness of the training delivery for effective skills acquisition and employment (Peña 2010; Finn et al. 2014). The lack of clear selection criteria risks a waste of human and financial resources, and a potential diversion of resources from the needy beneficiaries who have the greatest ability to utilise acquired skills for income-generating activities in order to improve their living conditions (Finn et al. 2014). Md Islam and Ahmadullah Mia (2007) state that during the selection process, the centre managers ought to determine whether a prospective trainee for self-employment has a viable business idea and knows the market, supply and demand for the relevant product or services.

To make NFET effective for productivity and employment, Palmer (2008) suggests that training must be needs-led, both with respect to the particular category of trainee and their particular skills needs; thus constructing a match between adult training provision and required skills. According to Robert Jjuuko and Topher Kwiri (2010), the aspect overlooked by most of the centres in the training needs assessment (TNA) process is the technical and/or business skills gap of the prospective trainees which needs to be addressed for paid employment, self-employment or micro-enterprise opportunities.

In sum, effective internal training delivery requires NFET programmes which contribute to skills acquisition and employment outcomes relevant to paid or self-employment. The internal delivery factors influencing this outcome, which formed the background to this study, include a clear objective for paid and/or self-employment, financial resources, clear selection criteria, a feasible business idea related to the market, and matching training needs with trainees' technical and/or business skills gaps.

\section{Study context and methodology}

\section{NFET in KwaZulu-Natal}

As mentioned earlier, KwaZulu-Natal (KZN), comprising of urban, semi-urban and deep rural areas, is among the three poorest of South Africa's nine provinces. Here 5.3 million people are living in poverty and 1.2 million people can hardly afford three meals a day (KZN-DoH 2010; May 2010). This poverty is caused by limited employable skills among adults on the one hand, and the lack of employment opportunities in the province on the other. Both government NFET centres and those run by non-profit organisations (NPOs) are providing technical and entrepreneurial skills training to rural and urban adults to enable them to take up paid or self-employment in the fields of agriculture, industry, services and small business activities. Despite these efforts, however, research has shown that NFET centres in KZN and their adult trainees continue to experience challenges due to the insufficiency of enabling environments (DHET 2012; Aitchison 2007).

\section{Methodology}

The study utilised a mixed methods research design (Creswell 2013). The qualitative component involved multiple case studies and the quantitative component was a survey (Babbie and Mouton 2007; Werner 2004). The sample was drawn from the education districts of Umlazi, Pinetown, ILembe and uMgungundlovu (Msunduzi) in KZN province. The 
sample consisted of NFET centres, managers, trainers and adult trainees from both urban and rural settings, from public and private NFET centres. ${ }^{3}$

In the context of non-probability sampling, purposive sampling was used as a supplement to the stratified method (Nieuwenhuis 2012) to select 21 centres out of 326 (KZN-DoE 2012). ${ }^{4}$ The sample of 21 NFET centres consisted of 15 public AET centres under the supervision of the Department of Education; and the other 6 centres were from the private sector. Within the selected 21 NFET centres, the sample consisted of 472 participants, of which 420 were trainees, 21 were centre managers and 31 were trainers (instructors). To complement quantitative data, 5 out of 21 managers were selected for one-on-one interviews. Their selection was based on whether the NFET centres they managed made provision for at least one of the following additional criteria: Post-training follow-up and support programmes for paid or self-employment; linkages with public institutions and agencies or private sectors; linkages with social networks, associations and employers and mentorship and psychological support programmes for self-employed trainees.

The data collection (over a period of 12 months) and analysis were primarily done by the first author of this paper for his doctoral study (Mayombe 2014). Self-administered questionnaires were used to collect quantitative data from adult trainees, trainers and centre managers (Maree and Pietersen 2012) and data were analysed using Statistical Packages for Social Sciences (SPSS) software. Semi-structured interviews and field observation were used for data collection in the qualitative study (Creswell 2009) and data were analysed through thematic analysis (Nieuwenhuis 2012; Fouché and Bartley 2011). Data were coded, then sorted and classified to find common themes and sub-themes to be matched and compared with the findings on the sections and sub-sections of the quantitative findings. The study was ethically cleared by the University of Pretoria and permission to conduct the study was granted by the KwaZulu-Natal Department of Education and relevant NPO managers. Participation was voluntary and participants gave their written informed consent.

\section{Findings}

In the presentation of the findings below, we begin with the quantitative findings, followed by the presentation of the qualitative findings on the related themes which emerged from the interviews. The quantitative and qualitative findings are then jointly interpreted in order to illuminate the views and concerns of managers, trainers and trainees in an integrated manner.

\section{Socio-economic and demographic characteristics of the trainees}

The majority of the trainees enrolled in the 21 centres were females $(83.6 \%$, or 351 out of 420 in absolute numbers) as compared to males (16.4\%, or 69/420). This finding indicates that adult training programmes constitute a second chance especially for women, who are more vulnerable and unskilled than their fellow male citizens (KZN 2013), to complete their basic education and gain skills in order to overcome poverty. Half of the respondents $(50.5 \%$, or 212/420) had been unemployed for more than five years. The analysis of the type of work (if any) they were engaged in before joining a course at the adult training centre revealed that almost half (48.8\%, or 205/420) of trainees were unemployed during the time of application for skills training at adult education centres. ${ }^{5}$ Only $16.7 \%$ (or 70/420). had had part-time jobs. Very few $(8.1 \%$, or $34 / 420)$ had had full-time jobs in the formal and informal sectors. 
The age of the trainee respondents was diverse. The age cohort 18-25 composed $20 \%$ (or $84 / 420$ ); $26-35$ constituted $34.4 \%$ (or $144 / 420$ ); $36-45$ totalled $28.6 \%$ (or $120 / 420$ ); $46-55$ equalled $14.5 \%$ (or 61/420), and 56 and above represented $2.6 \%$ (or 11/420). It is evident that the three largest age cohorts (18-25, 26-35 and 36-45) constitute the main band of working age and hence a group of citizens who can meaningfully contribute to the economy of the country if they acquire relevant skills training.

The analysis of the highest level of formal schooling reveals that only $20.7 \%$ (or 87/420) of trainees had completed the final year of schooling (Grade 12). More than a quarter $(27.4 \%$, or 115/420) of respondents had completed Grade 11;20.5\% (or 86/420) left school in grade 10; and $9.8 \%$ (or 41/420) of trainees completed Grade 8 . The lowest school achievers were those who only completed primary school (5\%, or $21 / 420$ ) and $4.8 \%$ (or 20/420) completed some primary school. In sum, the data confirm the KwaZulu-Natal Growth and development plan 2011-2030 to target socio-economically vulnerable adults (such as young adult orphans, youth in the street and domestic workers) from marginalised rural and urban-slum communities (KZN 2013). All these characteristics of the trainee sample are summarised in Table 1.

Table 1: Socio-economic and demographic characteristics of trainee sample

Gender

Employment/unemployment

Level of education (formal schooling)*

Age

\section{Female}

Male

More than 5 years of unemployment before enrolling in NFET centre

Unemployed at time of enrolment

Part-time job prior to enrolment

Full-time job prior to enrolment

$18-25$

$26-35$

$36-45$

$46-55$

$56+$

Completed Grade 12

Completed Grade 11

Left school after Grade 10

Completed Grade 8

Completed primary school (Grade 6)

Left primary school before completing Grade 620

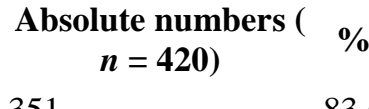

69

\footnotetext{
* In the South African formal education system, primary school encompasses Foundation Phase (Grades R-3) and Intermediate Phase (Grades 4-6). Secondary school involves Senior Phase (Grades 7-9) and Further Education and Training (FET) Phase (Grades 10-12)
}

\section{Training programme objectives and graduates' employment outcomes}

The duration of the training varies from three months to one year depending on the type of centre (public or private), the type and focus of training course (in terms of content) and the objective of the programme (in terms of whether it is designed towards paid or selfemployment). In some NFET centres involved in the study, the training programme 
objectives (paid employment or self-employment) guided the centres in choosing the right strategies and mechanisms in conducting training needs assessment, selection of the prospective trainees, training approach or methods, and the types of post-training support given to graduates. Table 2 presents the training programme objectives in relation to the type of centre.

Table 2: Training programme objectives according to nature of the centre (total responses: 21)

\begin{tabular}{|c|c|c|c|c|c|c|}
\hline \multirow[t]{2}{*}{ Variable } & \multicolumn{2}{|c|}{ Public (KZN-AET) } & \multicolumn{2}{|c|}{ CBO, FBO) } & \multicolumn{2}{|c|}{ Total sampl } \\
\hline & $\mathbf{n}$ & $\%$ & $\mathbf{n}$ & $\%$ & $\mathbf{n}$ & $\%$ \\
\hline Paid employment & & 26.66 & 1 & 16.66 & 5 & 23.8 \\
\hline Self-employment & 2 & 13.34 & 3 & 50 & 5 & 23.8 \\
\hline Both & 9 & 60 & 2 & 33.34 & 11 & 52.4 \\
\hline Total & 15 & 100 & 6 & 100 & 21 & 100 \\
\hline
\end{tabular}

Notes KZN-AET means Adult Education and Training (AET) centres managed by Provincial Department of KwaZulu-Natal (KZN). NPO, CBO, FBO refer to non-profit, community-based and faith-based organisations

Table 2 reveals that the training programmes of more than half $(52.4 \%)$ of the centres aimed at both paid employment and self-employment. However, a separate analysis of centre types shows that the majority $(83 \%$, or $5 / 6)$ of private centres mainly focus on self-employment. Contrary to the quantitative findings, qualitative data show that the focus of training programmes in most of the public centres was on further education of their trainees at training colleges.

Interviews with public centre managers indicated that the skills training programmes at AET centres were specifically designed to provide trainees with basic technical skills or business skills. When trainees completed AET level 4 (equivalent to Grades 8 and 9 of the South African National Qualification Framework 1), they were supposed to register with an FET college for further training in the specific skills area in order to enter paid employment in the public or private sector. Regarding the focus of the adult NFET programmes in KZN, two public centre managers explained:

As centre managers we are not allowed to design our own skills programmes which suit our adult trainees and communities. As a result, adult trainees in the communities are driven by curriculum and not by the market. This means that once they graduate from level 4 here, for them to get a job they must go for further training at Further Education and Training (FET) colleges far away from the community. Many of them do not go because they cannot afford taxi fare to town and food since they are poor. Some of them are old enough with family members to care for.

Trainees who completed their AET level 4 are recommended by UMALUSI [Certification Board] to pursue further education at FET colleges to acquire more skills for employment. The government grants bursaries to adult trainees who apply for admission to FET Colleges.

Qualitative research findings indicate that a first disabling environment factor was a disagreement between public centre managers and the Provincial Department of Education on the focus of the training programmes in the public centres. Managers would like the adult trainings to only focus on immediate self-employment instead of paid employment after 
graduating from FET colleges. A second disabling environment factor consists of the disagreement on training objectives between older and younger trainees in the public centres. Nevertheless, older trainees want to become self-employed immediately after graduation. These disagreements on the objective of the programmes influence the training delivery environment for skills acquisition.

It was evident from field observations that skills training programmes in the public centres served a dual purpose: self-employment for older trainees and a national certificate for youths. In the case of youths, some graduates residing in cities gained access to FET colleges. These trainees placed a great emphasis on gaining the certificates, and the trainers taught aspects covered in the official examinations. By so doing, trainers were overlooking the aspects of skills acquisition training for an immediate paid or self-employment objective of the older trainees.

By contrast, the provision of skills training programmes in most private centres (run by NPOs, community-based organisations [CBOs] and faith-based organisations [FBOs]) main focus is on self-employment. Hence, the skills training approach is tailored towards immediate self-employment after graduation. It was observed that their skills training programmes were often linked to income-generating activities for poor and marginalised adults. According to the managers, the overall goal was to promote and develop entrepreneurs for sustainable small businesses at the same time.

\section{The lack of financial resources}

All 21 centre managers and 31 trainers involved in the study reported that a lack of financial resources was a major challenge which caused insufficient investment in training materials and equipment. Inadequate funding is a major problem impeding skills training delivery, especially in the public centres. No workshops for practical skills training were observed, and most of the public centres were even lacking training aids and material for theory lessons. During an interview, one manager, representing the views of the majority of the public centres, bitterly said:

It is very difficult to continue with our skills training programme because the centre lacks financial support to buy material resources. The centre is located in a community where tourists most often come and buy some artefacts. But we cannot produce artefacts like the beads they need, because our centre lacks sponsorship for material resources.

In view of insufficient government funding for adult skills training in KZN and the zeal to provide skills to adults, managers and trainers in public centres resorted to contributing money from their own pockets to buy training materials for trainees and for practical training sessions.

Potentially, private centres are in a better position than public ones to organise support in terms of finance, materials, labour and technical assistance. Interviews with the centre managers and field observations revealed that private centres are supported by occasional national and foreign donations. Some private centres have a well-organised base with established channels for local fund-raising. This was the case for two centres catering for sewing and fashion design skills to poor women and people with disabilities in an urban district. The projects were initiated by local churches and depended on the goodwill and 
active interest of the church leaders whose members supported them financially and materially.

The findings indicate that NFET centres, and in particular public centres which provide skills training mainly in rural areas, face increasing financial challenges for the management of good quality adult skills training programmes. By contrast, private centres managed by NPOs or FBOs mostly tend to provide skills training to adults in urban areas, often benefiting from a well-organised base to secure resource support from local agencies and churches.

\section{The trainee selection criteria of NFET centres and employment outcomes of graduates}

Setting selection criteria for skills training was a significant element of all the private centres and a few public centres. Trainees were selected on the basis of certain factors required either for paid employment or for setting up a small business in the specific field of training. As shown in Fig. 1, the criteria helped some centres to admit suitable candidates to the programme, which was intended to promote the effectiveness of the training programmes.

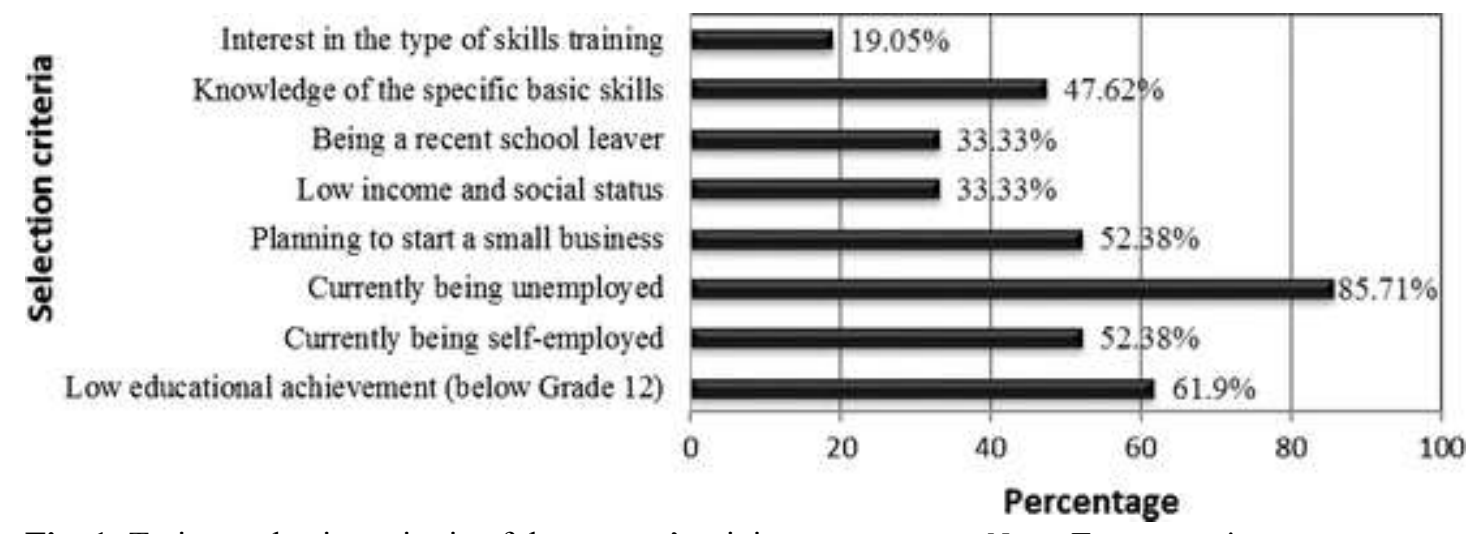

Fig. 1: Trainee selection criteria of the centres' training programme. Notes Frequency is a response to a multiple choice question and refers to the number of times each selection criterion was mentioned. Although few centre managers mentioned only one of the eight criteria, there were many who ticked more than one criterion. Source Mayombe 2014, p. 135

Figure 1 presents eight selection criteria which both public and private NFET centres had in common. The majority of the centres $(85.71 \%$, or 18 out of 21$)$ selected their trainees on the basis of being unemployed at the time of selection. Low educational achievement (below Grade 12) was the second criterion, scoring $61.9 \%$ (or 13/21); followed by being selfemployed at the time of selection $52.38 \%$ (or 11/21) and planning to start a small business $52.38 \%$ (or $11 / 21$ ). Less than half of the centres $(47.62 \%$, or $10 / 21)$ selected their prospective trainees on the basis of knowledge of the specific basic skills. Another criterion was the fact of being a recent school leaver $(33.33 \%$, or $7 / 21)$. Low income and social status was used as criterion to select the poorest of the poor trainees in the community $(33.33 \%$, or $7 / 21)$. Somewhat surprisingly, having an interest in the type of skills training received little importance, scoring only $19.05 \%$ or $(4 / 21)$.

The qualitative research findings reveal that in private centres, trainees underwent more rigorous selection processes than in public centres. In interviews, four out of five managers of private centres reported that the training was linked to the future establishment of an individual or collective small business. This is why a centre had to determine whether a trainee already had a small business or had a plan for starting one. On the other hand, public centre managers reported that a trainee merely underwent a written test to determine his/her 
reading and writing ability and class level. In practice, enrolment for training programmes at public centres was mostly done through trainees' self-selection. The centre managers were required to enrol a significant number of trainees, regardless of the selection criteria for a specific training programme, to avoid a closure of the centre by the Department of Education. In sum, the nature of the centres clearly creates different internal enabling environments in terms of selection criteria for skills training.

\section{Training needs assessment at the centres and graduates' employment outcomes}

A comparative analysis between the types of centres and whether managers and trainers consulted the trainees on their training needs before enrolment reveals that this was indeed done. On the part of public centres, $94.73 \%$ (or 36/38) of managers and trainers agreed that trainees were asked about their training needs. With regard to the private centres, $78.57 \%$ (or 11/14) of managers and trainers agreed that trainees were asked about their training needs.

Similarly, trainees were asked whether they were consulted about their training needs prior to signing up for a training course within a programme. In the case of public centres, $69.75 \%$ (or 203/291) of trainees agreed that they were consulted for their training needs while $30.24 \%$ (or 88/291) did not agree. For those trained in private centres, $72.86 \%$ (or 94/129) said that they were consulted, whereas $27.13 \%$ (or 35/129) indicated that they were not consulted. Thus in both public and private centres, the great majority of the trainees were asked about their training needs.

However, it is important to know how the training needs assessment (TNA) of the trainees was conducted in each of the centre types. Figure 2 presents the TNA process from trainees' responses by centre types. The percentages in Fig. 2 are within centre type.

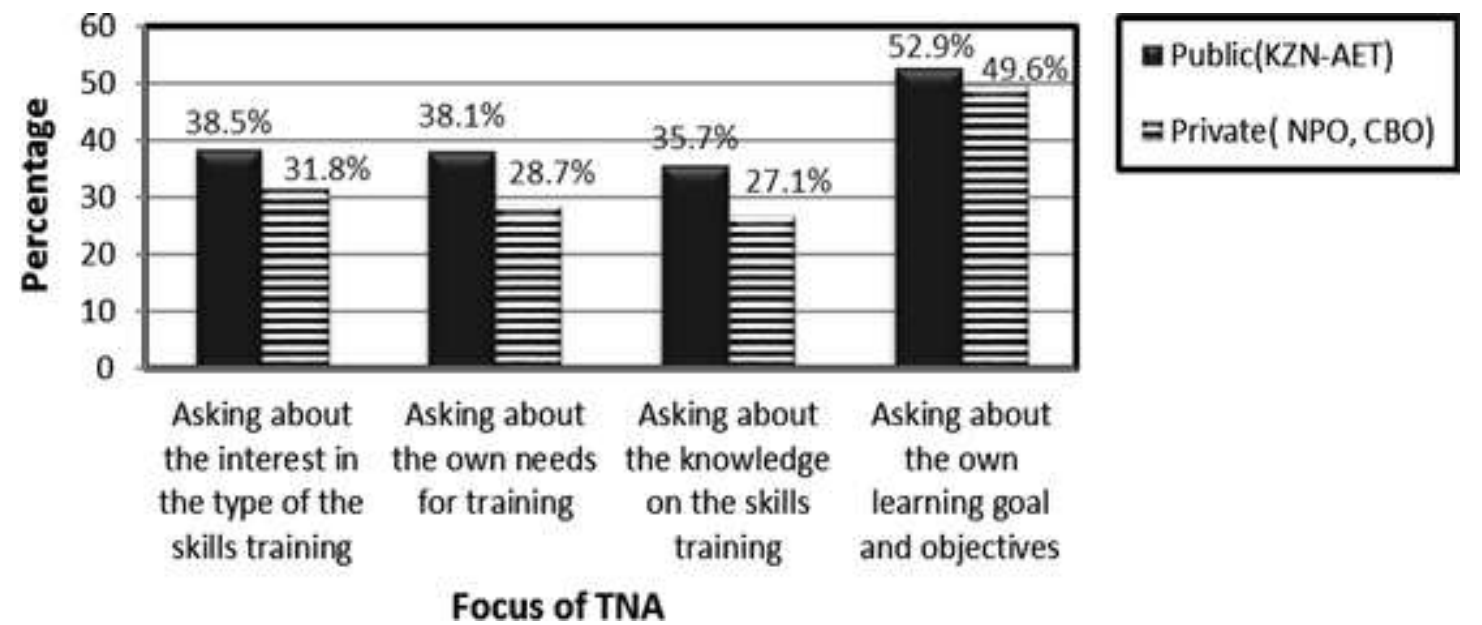

Fig. 2: The focus of trainees' training needs assessment (TNA) by centre type (total responses: 420). Source Mayombe 2014, p. 147

Figure 2 reveals that there is only a slight difference between the two types of NFET centres in the TNA process. Responses from trainees show that the primary emphasis was on "asking about their own learning goal and objectives", which scored $52.9 \%$ (or 154/291) for the public centres and $49.6 \%$ (or 64/129) for the private centres. The second main emphasis was on "asking about trainee's interest in the type of the skills training", which scored $38.5 \%$ (or $112 / 291$ ) in the public centres and $31.8 \%$ (or 41/129) in the private centres. 
When asked about conducting a market survey, none of the centre managers reported to have conducted socio-economic surveys or market opportunity surveys in order to identify potential market opportunities for both paid and self-employment in the local communities. Findings reveal that managers and trainers of both public and private NFET centres overlooked the link between the training programmes and the local economy during the process of TNA.

\section{Discussions of findings}

With regard to the extent to which the internal enabling environments of adult NFET centres contribute to skills acquisition and employment, the empirical findings of this study reveal both enabling and disabling factors of NFET centres.

The establishment of clearly defined skills training objectives was an internal enabling environment in private centres, and disabling in public centres. In an enabling context, specific training delivery components and activities are designed to ensure that the training objective is achieved (King 2012). Most private centres focus on a single objective, whether paid employment or self-employment, and target a single category of trainees. These findings correlate with the findings of a study in India (Palmer 2008), where training was tailored to meet local market demand with a specific pre-focused objective of either paid or selfemployment.

However, in most public centres internal disabling environment in terms of training delivery depicts the absence of a linkage between the target trainee group, the training objective (paid or self-employments) and the training delivery approach. Public centre managers would like to have more freedom to adapt the curriculum in a flexible manner to respond to the informal micro-enterprise demand and suit the self-employment needs of older trainees. Our findings show that the training programmes of public centres are struggling with the "top-down" model of delivery (Palmer 2008). In the context of NFET in KwaZulu-Natal, this means that the public centre managers and trainers focus on the authoritative decisions the Provincial Department of Education. Centre managers have to choose training courses from a list provided by the Provincial Department of Education irrespective of their community's economic environment and hence the market. They have to comply with specific decisions and therefore any training focus and new activities must be approved by the authorities of the Department of Education. This type of adult training delivery results in the programme becoming a curriculum-led training instead of being demand-led (King and Palmer 2007; Palmer 2008).

A lack of financial resources results in insufficient investment in human and material resources and hence impacts on skills acquisition, however this is more marked in public centres than in private centres. This finding is similar to those emerging from studies conducted by King and Palmer (2007) and Owusu-Mensah (2007) in Ghana. Their studies reveal that the lack of centres' financial resources to buy training tools and equipment was one of the challenges leading the Skills Training and Employment Placement (STEP) programmes to create "half-baked" skills acquisition (King and Palmer 2007, p. 51). The findings of a study in Denmark (GHK 2011a) revealed that municipalities are responsible for collecting taxes and financing adult NFET within their respective skills training fields. Private institutions and NPO partners contribute to the financial frameworks of NFET in Denmark by paying their share of the costs of adult education and training (ibid.). In 
Germany, stakeholders who finance NFET include companies, unions, local authorities, chambers of commerce, as well as individual learners (GHK 2011b).

The trainee selection criteria of centres' training programmes constitute enabling environments in private centres. John Patrick and Christiana Ijah (2012) concur that selecting trainees who intend to use the training skills to start their own business contributes to skills acquisition and employment outcomes (ibid.). These findings correlate with findings from Henry Espinoza Peña's (2010) study revealing that the training proved to be effective because trainees who fulfilled the preliminary selection criteria were called back for a more detailed evaluation of their eligibility for the training.

By contrast, in most public NFET centres, failure in the selection process disabled the effectiveness of the internal training delivery environment. A number of studies confirm that when adult training programmes for employment admit target beneficiaries with clear selection criteria for the training, the effectiveness of skills acquisition will be achieved (Patrick and Ijah 2012; Peña 2010; Finn et al. 2014). Likewise, the lack of clear selection criteria may result in a waste of financial resources.

The process of the training needs assessment (TNA) was not based on trainees' felt needs for immediate income-generating activities, but on what is offered in the centre. In most of the centres, the TNA did not consider bridging the gap between trainees' felt needs on the one hand, and their basic skills, experience and the paid or self-employment opportunities in the community on the other. Jjuuko and Kwiri (2010) argue that what most adult training centres overlook in the TNA process is the technical and/or business skills' gap of the prospective trainees for purposes of paid employment or micro-enterprise opportunities. Based on the socio-economic characteristics of trainees, indicating that at the time of their enrolment more than half of the respondents $(50.5 \%$, or 212 out of 420) had been unemployed for more than five years, one finding is that trainees could not be motivated by interest, but by an immediately felt need for income or for the survival of the family. This finding is aligned with the purpose of Adult Education and Training as stated by DVV International (2011, p. 4), which is "helping people and giving them opportunities to learn and practice the skills they need to improve the conditions under which they live and shape their own lives."

\section{Conclusions and recommendations}

It is evident from our findings that in most public NFET centres in KwaZulu-Natal there is a disjunction between internal training delivery components and the pursuit of training objectives, be they paid employment or self-employment. Therefore, provision of NFET programmes without a clear objective for the beneficiaries limits the outcome of finding employment. By contrast, private centres play a limited, but in some ways significant role in adult NFET programmes. They endeavour to create internal enabling environments for skills acquisition by focusing on income-generating activities in small businesses, either as an individual or in groups.

The lack of NFET centres' financial resources is one of the major internal disabling factors which are causing low investment in human and material resources. In addition, for both public and private centres, insufficient training needs assessment features as a substantial weakness. It does not consider closing the gap between the felt needs on the one hand, and a trainee's knowledge, experience and understanding of the opportunities of paid or selfemployment on the other. The absence of market opportunity surveys in order to identify 
potential market opportunities implies that the centre managers and trainers are overlooking the relationship between their training programmes and the local economy during the process of TNA. In turn, a market opportunity survey could inform the content of Capacity-Based Training (CBT) with major activities designed to contribute to skills acquisition and successful employment outcomes for NFET graduates.

Finally, we conclude that there is a significant correlation between training programme objectives, financial resources of the NFET centres, trainee selection criteria, the process of training needs assessment and the success of internal delivery environments for skills acquisition and employment outcomes of NFET graduates. The implication of the study's findings is that there is a need for the Department of Education, other concerned government departments and the private sector to improve the internal delivery environments of adult NFET centres to serve unemployed adults by providing them with employable and marketable skills. Without improvement of these internal enabling factors, adult trainees will continue to struggle for integration into the labour market and/or participation in the economic activities of KZN (Aitchison 2007; Mjoli 2007), a situation which will perpetuate unemployment and chronic poverty.

Based on our findings and conclusions, we have three recommendations. First, NFET centre managers should have a clear objective of skills-for-jobs and self-employment according to age cohorts. Second, through interviews, centre managers and trainers should consider closing the gap between the felt needs of trainees on the one hand, and their basic skills, experience and paid or self-employment opportunities on the other. Third, selection criteria must be tailored to trainees' need for paid employment opportunities and/or for immediate income-generating activities.

Footnotes

${ }^{1}$ Statistics South Africa actually calculates three lines of poverty - the food poverty line (FPL), the lower-bound poverty line (LBPL) and the upper-bound poverty line (UBPL). Those below the FPL don't have enough money to buy enough food to meet a daily minimum energy intake. Those below the LBPL don't have enough resources to purchase both enough food as well as non-food items, so they have to do without some food to pay for things like transport. The UBPL group are still poor, but generally manage to purchase both food and non-food items.

${ }^{2}$ Launched in 2004, the South African Expanded Public Works Programme (EPWP) aims for "decent employment through inclusive economic growth". For more information see http://www.epwp.gov.za/ [accessed 27 September 2015].

${ }^{3}$ In this paper, "private centre" means a non-profit training centre managed by non-profit organisations (NPOs), community-based organisations (CBOs) and church or other faithbased organisations (FBOs).

${ }^{4}$ According to KZN-DoE (2012), the total number of NFET centres in the four selected districts for research (ILembe, Pine Town, Umlazi and UMgungundlovu), is 326.

${ }^{5}$ Not all of the enrolled participants were out of work at the time of training. Some had a parttime job or were self-employed, and they continued working because the majority of NFET centres operate in the evening. 


\section{Acknowledgments}

This research was supported by a Research Support Bursary from the University of Pretoria, under whose supervision the study was conducted.

\section{References}

Aitchison, J. (2007). South Africa: Non-formal education. Country profile prepared for the Education for All Global Monitoring Report 2008: Education for All by 2015: will we make it? 2008/ED/EFA/MRT/PI/26. Paris: UNESCO. Retrieved 12 August 2015 from http://unesdoc.unesco.org/images/0015/001555/155520e.pdf.

Akpama, S. I., Esang, O. U., Asor, L. J., \& Osang, W. O. (2011). Non-formal education programmes and poverty reduction among young adults in Southern Senatorial District, Cross River State, Nigeria. Journal of Educational and Developmental Psychology, 1(1), 154-161.

Anderson, B. (2012). Converting asset holdings into livelihood: An empirical study on the role of household agency in South Africa. World Development, 40(7), 1394-1406.

Armstrong, P., Lekezwa, B., \& Siebrits, K. (2008). Poverty in South Africa: A profile based on recent household surveys. Stellenbosch Economic Working Papers: 04/08. Cape Town: University of Stellenbosch.

Babbie, E., \& Mouton, J. (2007). The practice of social research. Cape Town: Oxford University Press.

Blaak, M., Openjuru, G. L., \& Zeelen, J. (2012). Non-formal vocational education in Uganda: Practical empowerment through a workable alternative. International Journal of Educational Development, 33(1), 88-97.

Creswell, J. W. (2009). Research design: Qualitative, quantitative, and mixed methods approaches (3rd ed.). Los Angeles: Sage Publication Inc.

Creswell, J. W. (2013). Qualitative inquiry and research design: Choosing among five approaches. Los Angeles: Sage.

DHET (Department of Higher Education and Training). (2012). Green paper for post-school education and training. 30 April. Retrieved 18 July, 2013 from http://www.dhet.gov.za/portals/Documents/ Publications/Green Paper.pdf.

Dunkley, G. (2008). Technology-based vocational skills training for marginalized girls and young women. Bangkok: UNESCO Bangkok.

DVV International (Institut für internationale Zusammenarbeit des Deutschen Volkshochschul-Verbandes). (2011). Non-formal skills training. Adult education for decent jobs and better lives. Adult education and development supplement. Bonn: DVV International. 
Finn, A., Baxter, D. \& Onur, M. (2014). Making vocational training work: Study of vocational training in DDR, Rwanda. Retrieved 23 July 2014 from

http://www.tdrp.net/PDFs/TDRPMakingVocatTrainingWorkRwanda.pdf.

Fouché, C. B., \& Bartley, B. (2011). Quantitative data analysis and interpretation. In A. S. De Vos, H. Strydom, C. B. Fouché, \& C. S. L. Delport (Eds.), Research at grass roots: For the social sciences and human service professions (4th ed.). Pretoria: Van Schaik Publishers.

Georgiadou, G., Kekkeris, D., \& Kalantzis, M. (2009). A discussion of non formal education training programs for Roma women in Greek Thrace: Proposals for a better planning. The International Journal of Humanities, 6(9), 79-86.

GHK. (2011b). Country report on the action plan on adult learning: Germany (March 2011). Retrieved 07 June 2014 from http://ec.europa.eu/education/adult/doc/germany_en.pdf.

GHK (Goldman Hodgkin Katz). (2011a). Country report on the action plan on adult learning: Denmark (March 2011). Retrieved 07 June, 2014 from Available at http://ec.europa.eu/education/adult/doc/denmark_en.pdf.

Islam, M., \& Mia, A. (2007). The innovative elements in non-formal education of Bangladesh: Perspective of income generating programmes for poverty alleviation. International Journal of Education and Development using Information and Communication Technology, 3(3), 89-104.

Islam, M., Mia, A., \& Sorcar, N. R. (2012). Income-generation perspective in non-formal education NGO initiatives in Bangladesh. Asia-Pacific Journal of Social Work and Development, 15(1), 17-29.

Jjuuko, R. \& Kwiri, T. (2010). Report of needs assessment study for skills training and nonformal education for poverty reduction in Karamoja. Retrieved 23 July 2014 from http://ugaaden.ac.ug/documents/NeedsAssessmentStudyReportforKaramojaProject2010finald raft[1].pdf.

Kedrayate, A. (2012). Non-formal education: Is it relevant or obsolete? International Journal of Business, Humanities and Technology, 2(4), 1-5.

King, K. (2012). Eight proposals for a strengthened focus on Technical and Vocational Education and Training (TVET) in the Education for All (EFA) agenda. Background paper prepared for the Education for All Global Monitoring Report 2012. Paris: UNESCO.

Retrieved 22 September 2015 from http://www.unesco.org/new/fileadmin/MULTIMEDIA/HQ/ED/pdf/gmr2012-ED-EFA-MRTPI-06.pdf.

King, K., \& Palmer, R. (2006). Skills, capacities and knowledge in the least developed countries: New challenges for development cooperation. Background paper for the 2006 UNCTAD Least Developed Countries Report. Edinburgh: Centre of African Studies.

King, K. \& Palmer, R. (2007). Skills development and poverty reduction: A state of the art review. European Training Foundation. Retrieved 28 May, 2013 from 
http://www.etf.europa.eu/pubmgmt.nsf/(getAttachment)/B055AACF8E9CC19DC12573AF0 0520109/\$File/NOTE79TKHJ.pdf.

KZN (KwaZulu-Natal Province). (2013). Provincial growth and development plan 20112030. Pietermaritzburg. Retrieved 22 October 2014 from

http://www.kznppc.gov.za/Portals/0/Documents/13-09-11PGDPVersion203.pdf.

KZN-DoE (2012). Adult education and training and FET college report - 2012.

Pietermaritzburg: KwaZulu-Natal Department of Education.

KZN-DoH (KwaZulu-Natal Department of Health). (2010). Strategic plan 2010-2014. Pietermaritzburg: KwaZulu-Natal Department of Health. Retrieved 23 July 2013 from http://www.kznhealth.gov.za/stratplan2010-14.pdf.

Leibbrandt, M., Woodard, I., Finn, A., \& Argent, J. (2010). Trends in South African income distribution and poverty since the fall of apartheid. OECD Social, Employment and Migration Working Papers, No. 101. Paris: OECD Publishing. Retrieved 24 September 2015 from http://www.oecd-

ilibrary.org/docserver/download/5kmms0t7p1 ms.pdf?expires=1443093320\&id=id\&accname $=$ guest $\&$ checksum $=$ C843F1BA82CDA237EF2A1329013C97F2.

Maree, K., \& Pietersen, J. (2012). Standardisation of a questionnaire. In K. Maree (Ed.), First steps in research (pp. 215-223). Pretoria: Van Schaik Publishers.

May, J. (2010). Poverty eradication: The South African experience. Paper presented at Department of Economic and Social Affairs, Division for Social Policy and Development and Economic Commission for Africa, Economic Development and NEPAD. 15-17 September, United Nations Conference Centre, Addis Ababa, Ethiopia. Retrieved 24 September 2015 from http://www.un.org/esa/socdev/social/meetings/egm10/documents/May\%20paper.pdf.

Mayombe, C. (2014). Assessment of non-formal adult education and training centres' enabling environments for employment and poverty reduction in KwaZulu-Natal, South Africa. Pretoria: University of Pretoria (PhD Thesis).

McGrath, S., \& Akoojee, S. (2007). Education and skills for development in South Africa: Reflections on the accelerated and shared growth initiative for South Africa. International Journal of Educational Development, 27(4), 421-434.

Mjoli, B. J. (2007). The implications of new policy and legislation on Non-formal Adult Education Programmes: A case study of the KwaZulu-Natal Poultry Institute. Pietermaritzburg: University of KwaZulu-Natal (MEd Dissertation).

Morton, M. H., \& Montgomery, P. (2011). Empowerment-based non-formal education for Arab youth: A pilot randomized trial. Children and Youth Services Review, 34, 417-425.

Nieuwenhuis, J. (2012). Qualitative research designs and data gathering techniques. In K. Maree (Ed.), First steps in research (pp. 69-97). Pretoria: Van Schaik Publishers.

Owusu-Mensah, F. (2007). Ghana: Non-formal education. Country profile prepared for the Education for All Global Monitoring Report 2008: Education for All by 2015: will we make 
it? 2008/ED/EFA/MRT/PI/56. Paris: UNESCO. Retrieved 12 June 2013 from http://unesdoc.unesco.org/images/0015/001555/155563e.pdf.

Palmer, R. (2007). Skills for work? From skills development to decent livelihoods in Ghana's rural informal economy. International Journal of Educational Development, 27(4), 397-420.

Palmer, R. (2008). Skills and productivity in the informal economy. ILO Employment Working Paper No. 5. Geneva: International Labour Office. Retrieved 22 September 2015 from http://www.ilo.org/public/english/employment/download/wpaper/wp5.pdf.

Palmer, R., Wedgwood, R., \& Hayman, R. (2007). Educating out of poverty? A synthesis report on Ghana, India, Kenya, Rwanda, Tanzania and South Africa. Edinburgh: Centre of African Studies, University of Edinburgh.

Patrick, J. M., \& Ijah, C. N. (2012). Adult and non-formal education programmes of nongovernmental organizations for poverty alleviation in Nigeria: What can be learnt from the Practice? Journal of Education and Practice, 3(11), 1-6.

Pauw, K. (2009). A profile of KwaZulu-Natal: Demographics, poverty, inequality and unemployment. Background paper series, Provide project. Retrieved 15 July 2014 from http://www.elsenburg.com/provide/documents/BPDemographicsKZN.pdf.

Peña, H. E. (2010). Impact evaluation of a job-training programme for disadvantaged youths: The case of Projoven. Maastricht: Boekenplan.

Preece, J. (2005). The role of education in poverty alleviation for sustainable development. Stirling: University of Stirling.

Preece, J. (2010). Response to learning through life: Thematic area of poverty reduction. International Journal of Lifelong Education, 29(4), 475-485.

Roberts, B. J. (2008). Chronic and transitory poverty in post-apartheid South Africa. Journal of Poverty, 5(4), 1-28.

RSA (Republic of South Africa). (2010). Adult education and training Act 25 of 2010. Published in the Government Gazette, (33853). Pretoria: Government Printers.

RSA (2012). The presidency: National planning commission. National development plan: Vision 2030. Pretoria: Government Printers.

Statistics South Africa. (2011). Gender statistics in South Africa, 2011. Pretoria: Government Printers.

Statistics South Africa. (2014). Quarterly labour force survey, Quarter 1, 2014. Pretoria: Government Printers.

UNESCO (2005). Education for all: The quality imperative. EFA Global Monitoring Report 2005. Paris: UNESCO. Retrieved 22 September 2015 from http://unesdoc.unesco.org/images/0013/001373/137333e.pdf. 
Werner, A. (2004). A Guide to implementation research. Washington, DC: The Urban Institute Press.

Woolard, I., Leibbrandt, M., \& McEwen, H. (2009). Poverty and inequality. In J. Hofmeyr (Ed.), Recession and recovery: 2009 transformation audit (pp. 94-125). Wynberg: Institute for Justice and Reconciliation. Retrieved 3 October 2013 from www.ijr.org.za/publications/pdfs/IJR_TA_Chapter4.pdf.

World Bank (2004). Skills development in sub-Saharan Africa. Washington, DC: The World Bank. 